\title{
EFFECTS OF SATURATED AND UNSATURATED FATS WITH VITAMIN E SUPPLEMENTATION ON THE ANTIOXIDANT STATUS OF BROILER CHICKEN TISSUES
}

\author{
F. Husvéth ${ }^{1 *}$, H. A. MANILLA ${ }^{1}$, T. GAÁL ${ }^{2}$, P. VAJDOVICH ${ }^{2}$, N. BALOGH ${ }^{2}$, L. WÁGNER ${ }^{1}$, \\ I. LÓTH ${ }^{1}$ and K. NÉMETH ${ }^{1}$
}

${ }^{1}$ Department of Animal Physiology and Nutrition, Georgikon Faculty, Pannon University of Agricultural Sciences, H-8360 Keszthely, Deák F. u. 16, Hungary; ${ }^{2}$ Department of Internal Medicine, University of Veterinary Sciences, H-1078 Budapest, István u. 2, Hungary

(Received July 12, 1999; accepted October 20, 1999)

The influence of fish oil (highly unsaturated) and beef tallow (highly saturated) with vitamin $\mathrm{E}(100 \mathrm{IU} / \mathrm{kg})$ supplementation on the antioxidant status of broiler chicken cockerels was investigated. Chicks were fed a control diet with no added fat, $40 \mathrm{~g} / \mathrm{kg}$ each of fish oil and beef tallow diets, respectively, from 11 to 42 days of age. Tocopherol concentration and the rate of lipid peroxidation, thiobarbituric acid reactive substance (TBARS) in liver, fatty acid composition of the liver lipids, blood serum total antioxidant status (TAS), and reduced glutathione (GSH) content were determined. Vitamin E supplementation of the diet increased liver $\alpha$-tocopherol content in chicks regardless of the type of dietary fat. Fish oil diet resulted in higher liver TBARS value while beef tallow diet showed lower values compared to the control diet. Vitamin E supplementation reduced liver TBARS as well as serum GSH, and raised serum TAS for all diets. Serum GSH was the same for vitamin E supplemented diets regardless of the fat supplement. Fish oil diets resulted in a significant increase in hepatic lipid n-3 PUFA content. A significant positive correlation was found between liver TBARS and n-3 PUFA content. No relationships were established, however, between liver TBARS and n6 PUFA or saturated fatty acids. The results suggest that feeding oils rich in n-3 PUFA increases tissue concentration of these fatty acids, consequently increasing tissue lipid peroxidation and reducing the antioxidative status of broiler chickens. Supplementing high levels of vitamin E with such oils may increase tissue oxidative stability. Serum TAS or GSH may be used as a measure of antioxidative status in chickens.

Key words: Dietary fat, broiler chickens, n-3 fatty acids, lipid peroxidation, vitamin $\mathrm{E}$

*E-mail: h5544hus@ella.hu; Fax: +36 (83) 314344 
Supplementation of broiler diets with small quantities of fats and oils has long been used for improving the consistency and palatability of meal (Summers and Leeson, 1979), for stimulating growth and for improving feed and energy util isation (Rand et al., 1958; Dam et al., 1959; Carew and Hill, 1964; Vermeersch and Vanschoubroek, 1968). In recent times, supplementation of poultry diets with $\mathrm{m}$ arine fish and plant seed oils has been used for enriching broiler chicken meat with beneficial n-3 fatty acids (Hulan et al., 1988, 1989; Farrell and Gibson, 1990; Sim, 1990; Olomu and Baracos, 1991). However, this procedure increases the polyu nsaturated fatty acid (PUFA) content of broiler chicken and possibly the rate of ti ssue lipid peroxidation (McKay and Kings, 1980; Molenaar et al., 1980). Tissue lipid oxidation generates free radicals and hydroperoxides (Herman, 1981) which not only damage cells and reduce the immune defence of the animal, consequently affecting production capacity, but also attack tissue PUFA causing off-flavour and oxidative rancidity of n-3 fatty acid enriched animal products ( Dawson and Gartner, 1983). The other problem that may arise is depletion of tissue tocopherols, which has been reported as a possible factor that promotes lipid peroxidation in meat (Marusich et al., 1975). Investigations on the reduction of tissue oxidation in chickens have been directed towards the supplementation of high levels of vitamin E in diets (Wood and Enser, 1997). Animals are unable to synthesise tocopherols and therefore depend on dietary sources (Chan and Decker, 1994). Unlike ma mmals, chickens have a rudimentary lymphatic system, which makes it possible for chylomicrons to be absorbed directly into the portal blood for transport to the liver, allowing direct exposure of the liver to dietary fats and fat-soluble vitamin E (Noyan et al., 1964). The tocopherol concentration of the liver has been widely used as an index for the assessment of vitamin E status in the animal (Desai, 1980). Vitamin E supplementation of poultry diets has been reported to increase $\alpha$ tocopherol content (Sheldon, 1984; Sheehy et al., 1991) and improve the antioxidative status of tissues (Sheldon, 1984; Lin et al., 1989; Sheehy et al., 1993; Cherian et al., 1996). The nature of dietary fats (degree of unsaturation of their fatty acids) has been reported to influence the thiobarbituric acid reactive substance (TBARS) value of chicken tissues (Cherian et al., 1996) and the cellular glutath ione-dependent antioxidant system (Christon et al., 1995). It has been suggested that reduced glutathione (GSH) protects cells against damage from free radicals through its combined action with vitamin E (Murphy et al., 1992). Studies with fish oils rich in n-3 PUFA have reported a decrease of GSH content in animal ti ssues (Nalbone et al., 1989; D'Aquino et al., 1991), in response to elevated lipid peroxidation. Thus, this study was conducted to evaluate the effects of feeding fats of different origin with vitamin $\mathrm{E}$ supplementation on the antioxidant defence, such as blood plasma total antioxidant status (TAS) and GSH of broiler chickens. The rate of lipid peroxidation (evaluated by TBARS), tocopherol content and lipid fatty acid composition in the liver were also measured. 


\section{Materials and methods}

\section{Source of supplemental fats and vitamin $E$}

Fish oil of marine origin was applied. Beef tallow was obtained from a local slaughterhouse. Their fatty acid composition is shown in Table 1. A mineralvitamin premix with different vitamin E levels was supplied by AgrocomplexCentral Soya Milling and Marketing Company (Agárd, Hungary). All products were stored at $4{ }^{\circ} \mathrm{C}$ prior to mixing.

Table 1

Fatty acid compositions of control diet, fish oil and beef tallow

\begin{tabular}{lccc}
\hline \multirow{2}{*}{ Fatty acids } & Control diet & Fish oil & Beef tallow \\
\cline { 2 - 4 } & \multicolumn{3}{c}{ \% total fatty acids } \\
\hline C14: 0 & - & 7.5 & 3.5 \\
C16: 0 & 21.3 & 13.8 & 28.3 \\
C16: $1 \mathrm{n}-7$ & - & 13.3 & 7.8 \\
C18: 0 & 0.7 & 2.0 & 10.7 \\
C18: $1 \mathrm{n}-9$ & 12.5 & 24.7 & 46.7 \\
C18: $2 \mathrm{n}-6$ & 61.2 & 1.9 & 1.0 \\
C18: $3 \mathrm{n}-3$ & 2.3 & 8.1 & - \\
C20: $2 \mathrm{n}-6$ & - & 4.1 & - \\
C20: $4 \mathrm{n}-6$ & 0.2 & - & - \\
C20: $5 \mathrm{n}-3$ & 0.1 & 9.1 & - \\
C22: $4 \mathrm{n}-6$ & - & 0.3 & - \\
C22: $5 \mathrm{n}-3$ & - & 1.4 & - \\
C22: $6 \mathrm{n}-3$ & & 8.8 & 2.0 \\
Others & 1.7 & 1.9 & 42.5 \\
SAT & & 22.3 & - \\
MUFA $^{2}$ & 22.0 & 38.0 & 1.0 \\
Total n-3 & 12.5 & 35.5 & 1.0 \\
Total n-6 & 2.4 & 1.3 & \\
PUFA & & &
\end{tabular}

${ }^{1} \mathrm{SAT}=$ saturated fatty acids; ${ }^{2} \mathrm{MUFA}=$ monounsaturated fatty acids;

${ }^{3} \mathrm{PUFA}=$ polyunsaturated fatty acids

\section{Birds and diets}

A total of 240 day-old Ross cockerels were obtained from a commercial hatchery (HE-ROSS Hatcheries Ltd., Ócsa, Hungary). Chicks were randomly a ssigned into cages ( 20 chicks per cage) in batteries with raised floors and fed a common basal broiler starter diet from 1 to 10 days. At day 11 chicks were ind ividually weighed, randomly reassigned to cages (10 chicks per cage) and fed the experimental diets (control diet with no added fat, $40 \mathrm{~g} / \mathrm{kg}$ each of fish oil and beef 
tallow, respectively) with (100 IU/kg; E+ groups) and without vitamin E (Egroups) supplementation. Levels of maize, wheat, barley and soybean meal of the basal diet (Table 2) were adjusted with a minimal amount $(20 \mathrm{~g} / \mathrm{kg})$ of fish meal added to achieve the same protein : energy ratio for all treatment diets. Fatty acid composition of the control diet is shown in Table 1.

\section{Table 2}

Composition and calculated nutrient content of the basal diet fed to chicks

\begin{tabular}{lc}
\hline \multicolumn{1}{c}{ Ingredients and composition } & $\mathrm{g} / \mathrm{kg}$ \\
\hline Yellow maize & 510.00 \\
Wheat & 167.00 \\
Soybean meal (44\%) & 268.00 \\
Fish meal, \% & 20.00 \\
Vitamin/mineral premix ${ }^{*}$ & 35.00 \\
Total & $1,000.00$ \\
Calculated nutrient content & \\
ME (MJ/kg) & 12.10 \\
Crude protein, g/kg & 195.0 \\
Crude fibre, g/kg & 35.0 \\
Lysine, g/kg & 10.2 \\
Methionine, g/kg & 3.26 \\
Methionine + cystine, g/kg & 6.46 \\
Vitamin E, IU/kg & 13.6 \\
\end{tabular}

${ }^{*}$ Provides per kilogram of diet: 15,999 IU vitamin A, 3299.8 IU vitamin $\mathrm{D}_{3}, 10.2 \mathrm{mg}$ vitamin $\mathrm{K}_{3}, 5.0 \mathrm{mg}$ vitamin $\mathrm{B}_{1}, 15.2 \mathrm{mg}$ vitamin $\mathrm{B}_{2}$, $20.2 \mathrm{mg}$ pantothenic acid, $4.0 \mathrm{mg}$ vitamin $\mathrm{B}_{6}, 0.06 \mathrm{mg}$ vitamin $\mathrm{B}_{12}$, $50.3 \mathrm{mg}$ nicotinic acid, $5.0 \mathrm{mg}$ folic acid, $0.4 \mathrm{mg}$ biotin, $600 \mathrm{mg}$ choline chloride; $100 \mathrm{mg} \mathrm{Zn,} 4.1 \mathrm{mg} \mathrm{I}, 0.2 \mathrm{mg} \mathrm{Se}, 100 \mathrm{mg} \mathrm{Mn}, 16.2 \mathrm{mg} \mathrm{Cu}$, $20.3 \mathrm{mg} \mathrm{Fe}, 715.00 \mathrm{mg}$ benduramycin

The diets were isonitrogenous $(195 \mathrm{~g} / \mathrm{kg} \mathrm{CP})$ and calculated to be isoene $\mathrm{r}$ getic $(12.4 \pm 0.2 \mathrm{MJ} / \mathrm{kg})$. Adequate amount of vitamins, minerals and essential amino acids were provided in accordance with the National Research Council (NRC; 1994) recommendations. Diets were prepared weekly and stored at $4{ }^{\circ} \mathrm{C}$ to reduce the rate of lipid oxidation.

Birds were raised within a controlled environment at 20 to $25{ }^{\circ} \mathrm{C}$. Additional heat was provided during the initial 2-week brooding period. Twenty-fourhour lighting was employed. Chicks were given free access to water and feed. A complete randomised design was used. The design produced 4 dietary replicates per treatment. 


\section{Sample collection}

Samples for chemical analysis were collected at 42 days of age. Six chicks per treatment were weighed, killed by severing the jugular vein, blood (without anticoagulant) and liver tissue samples were obtained and immediately stored in the deep freezer at $-20^{\circ} \mathrm{C}$.

\section{Chemical analysis}

The rate of lipid peroxidation was analysed by the determination of malonaldehyde (MDA) concentration according to the method of Placer et al. (1966). TBARS were then measured by using 1,1,3,3-tetraethoxypropane as standard and the results were expressed as $\mu \mathrm{mol}$ of malonaldehyde (MDA)/g wet tissue weight. The serum concentration of GSH was measured by a spectrophotometric method d escribed by Sedlak and Lindsay (1968). Total antioxidant status (TAS) was dete rmined with a colorimetric kit supplied by Randox Ltd. (Crumlin, Northern Ireland). Vitamin E ( $\alpha$-tocopherol) was determined from the liver tissue samples by a modif ication of the method described by McMurray et al. (1980). Portions (200-500 mg) of tissue samples were saponified by the addition of $2.5 \mathrm{ml}$ of $60 \%$ (w/v in water) $\mathrm{KOH}$ and $10 \mathrm{ml} \mathrm{5 \%}\left(\mathrm{w} / \mathrm{v}\right.$ in ethanol) followed by heating at $70{ }^{\circ} \mathrm{C}$ for $30 \mathrm{~min}$. After cooling, $20 \mathrm{ml} \mathrm{H} \mathrm{H}_{2} \mathrm{O}$ and $10 \mathrm{ml}$ petroleum ether $\left(40-70{ }^{\circ} \mathrm{C}\right.$ fraction) were added and the samples were mixed and allowed to stand for $1 \mathrm{~h}$ to allow phase separation. The $\mathrm{p} \mathrm{e}$ troleum ether extract was then dried under $\mathrm{N}_{2}$ at $40{ }^{\circ} \mathrm{C}$ and resolved in $1.0 \mathrm{ml}$ methanol. Ten-microlitre portions of the methanol extract were chromatographed on a high-performance liquid chromatograph (Spectra-Physics) equipped with BST RUTIN $10 \mu \mathrm{m} \mathrm{C}_{8}, 240 \mathrm{~mm}$ length $\times 4 \mathrm{~mm}$ internal diameter column (Bio-Separation Technologies, Budapest, Hungary). Chromatography was performed using a mobile phase of methanol-water $(98: 2, \mathrm{v} / \mathrm{v})$ at a flow rate of $1 \mathrm{ml} / \mathrm{min}$. Fluorimetric detection wavelengths were 292 and $330 \mathrm{~nm}$. Calibration was performed using standard solutions of $\alpha$-tocopherol in methanol (Fluka, Buchs, Switzerland).

Total lipid was extracted from liver tissue samples by the method of Folch et al. (1957). Four grams of tissue samples were homogenised with $80 \mathrm{ml}$ of a $2: 1(\mathrm{v} / \mathrm{v})$ mixture of chloroform-methanol after which $4 \mathrm{ml} 0.88 \% \mathrm{NaCl}$ was added, mixed and left to stand for $2 \mathrm{~h}$ to allow phase separation. The chloroform-methanol extract was evaporated to dryness in a water-bath at $50{ }^{\circ} \mathrm{C}$ under $\mathrm{N}_{2}$ flow. The lipid extracts were then converted to fatty acid methyl esters by using boron-trifluoride-methylation solution. The resultant fatty acid methyl esters were separated and analysed by gas liquid chromatography according to Husvéth et al. (1982). An automated gas-liquid chrom atography (Chrom 42), equipped with dual flame ionisation detector and a $1.8 \mathrm{~m}$ length $\times 3 \mathrm{~mm}$ internal diameter packed glass column containing 100/120 mesh Chromosorb WAW coated with $10 \%$ SP 2330 . The samples were analysed under the following o perating conditions: $250{ }^{\circ} \mathrm{C}$ injector and detector temperature, $20 \mathrm{ml} / \mathrm{min}$ nitrogen gas 
HUSVÉTH et al.

flow, and a programmed temperature change from the initial temperature of $185{ }^{\circ} \mathrm{C}$ for $2 \mathrm{~min}$ to the final temperature of $250{ }^{\circ} \mathrm{C}$ at a rate of $3.5^{\circ} \mathrm{C} / \mathrm{min}$. These conditions were chosen for separating fatty acids from 12 to 24 carbons in chain length. Fatty acids were identified by comparison of retention times with known external standard mixtures (PUFA-2: Catalogue No. 1081) quantified by a Shimadzu C-RGA integrator, and the results were expressed as a percentage distribution of fatty acid methyl esters. All chemicals used for gas chromatographic analysis were obtained from Supelco Inc. (Bellefonte, PA, USA).

\section{Statistical analysis}

The experiment used a complete randomised design with the experimental unit being the pen average for each performance variable. Data were subjected to analysis of variance, regression and correlation analysis using Statgraphics version 5.0 (1991) statistical package. Significant differences among means were determined using Duncan's multiple range test (1955). Significance was accepted at the 5\% co nfidence level. Data are expressed as means \pm standard error of the mean ( SEM).

\section{Results}

The alpha-tocopherol content of the chicks' liver was significantly increased by vitamin E supplementation regardless of the type of dietary fat (Fig. 1).

Comparing the effects of type of dietary fat in groups not supplemented with vitamin $\mathrm{E}$, fish oil and beef tallow resulted in a significant increase and decrease in liver TBARS, respectively, as compared to the control diet (Fig. 2). TBARS were $\mathrm{r}$ educed for all diets with vitamin $\mathrm{E}$ supplementation. Regression analysis between liver $\alpha$-tocopherol and TBARS concentration showed negative correlation $(\mathrm{r}=$ $-0.618 ; \mathrm{P}<0.001)$.

Plasma GSH and TAS levels are shown in Figs 3 and 4, respectively. The le vels of serum GSH were significantly depressed by vitamin E supplementation in chicks fed fish oil or beef tallow diets (Fig. 3). In vitamin E supplemented groups, the chicks' GSH levels were practically the same irrespective of the type of dietary fat.

The type of dietary fats (Table 3) significantly influenced the fatty acid co mposition of total hepatic lipids. The main effect was within the $n-3$ fatty acid content. Chickens fed fish oil had higher concentrations of hepatic C18:3n-3, C20:5n-3, $\mathrm{C} 22$ : 5n-3 and C22 : 6n-3 than those fed beef tallow or control diets. T otal monounsaturated fatty acids and C18:1n-9 were depressed in chickens fed the diet containing fish oil compared to those fed beef tallow or control diets. Vitamin E supplementation had no effect on the deposition of n-3 PUFA in the liver of chic kens. However, saturated fatty acid level (in liver lipids of chicks fed the diet co ntaining fish oil) and C16:0 level (in those fed fish oil and beef tallow diets, $\mathrm{r}$ e- 
spectively) were significantly increased by vitamin E supplementation. Regression analysis revealed a significant positive correlation between liver TBARS and $n-3$ PUFA (C18:3n-3 r = 0.474, P $<0.01 ; \mathrm{C} 20: 5 \mathrm{n}-3 \mathrm{r}=0.648, \mathrm{P}<0.001 ; \mathrm{C} 22: 5 \mathrm{n}-3 \mathrm{r}=$ $0.538, \mathrm{P}<0.001$; $\mathrm{C} 22$ : $6 \mathrm{n}-3 \mathrm{r}=0.642, \mathrm{P}<0.001$; total $\mathrm{n}-3 \mathrm{r}=0.645, \mathrm{P}<0.001$ ). No relationship was established between liver TBARS and n-6 PUFA or saturated fatty acids.

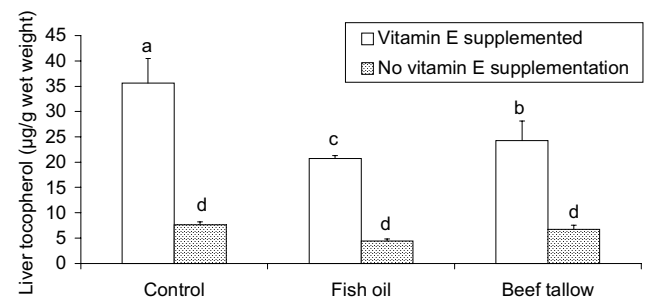

Fig. 1. Alpha-tocopherol content in liver of chickens as influenced by fat $(40 \mathrm{~g} / \mathrm{kg})$ and vitamin $\mathrm{E}$ $(100 \mathrm{IU} / \mathrm{kg})$ supplementation of the diet. Columns designated with different letters differ significantly $(\mathrm{P}<0.05)$

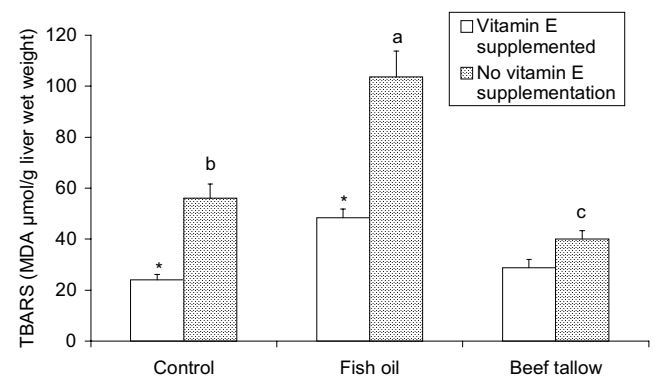

Fig. 2. TBARS (MDA) in liver of chickens as influenced by fat $(40 \mathrm{~g} / \mathrm{kg})$ and vitamin E supplementation $(100 \mathrm{IU} / \mathrm{kg})$ of the diet. Columns designated with different letters differ significantly $(\mathrm{P}<0.05)$;

* = significant difference between vitamin $\mathrm{E}$ supplemented and unsupplemented treatments $(\mathrm{P}<0.05)$

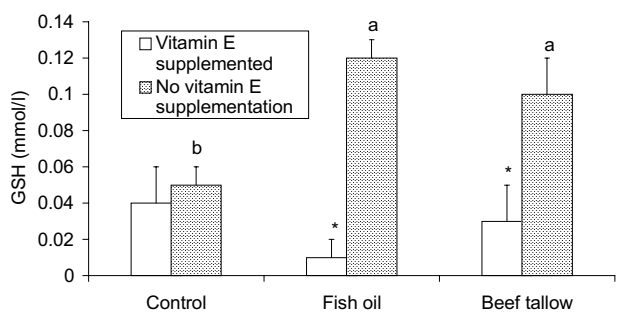

Fig. 3. Blood GSH levels of chickens as influenced by fat $(40 \mathrm{~g} / \mathrm{kg})$ and vitamin E (100 IU/kg) supplementation to the diet. Columns designated with different letters differ significantly $(\mathrm{P}<0.05)$;

$*=$ significant difference between vitamin E supplemented and unsupplemented treatments $(\mathrm{P}<0.05)$ 
HUSVÉTH et al.

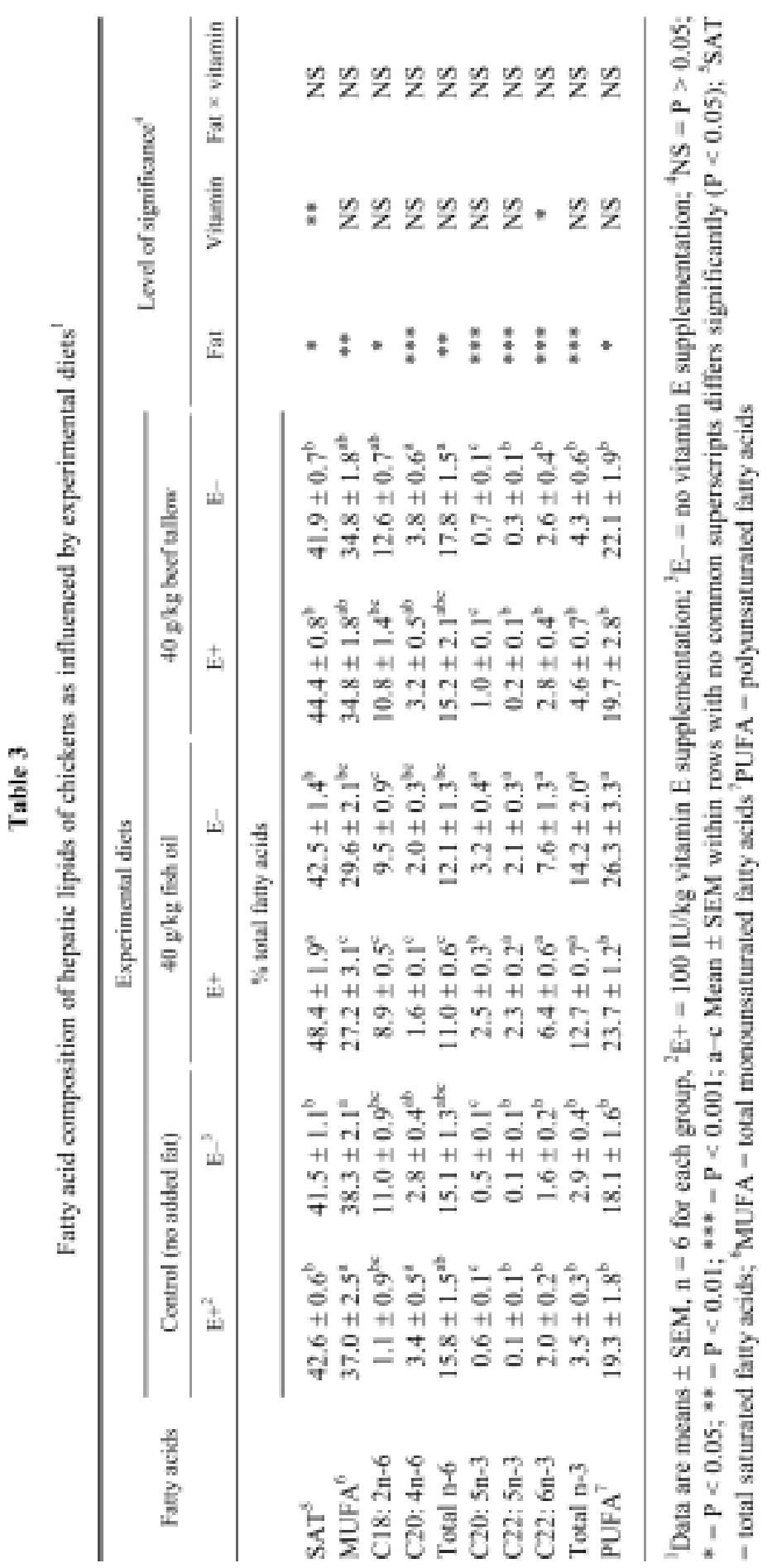




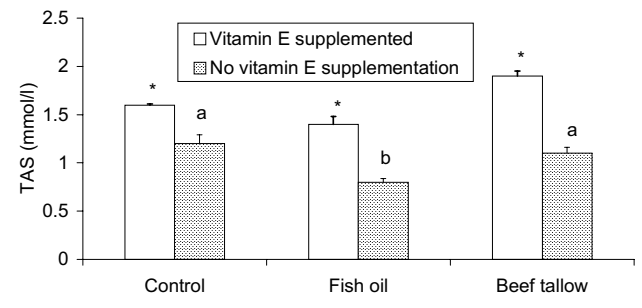

Fig. 4. Blood TAS values of chickens as influenced by fat $(40 \mathrm{~g} / \mathrm{kg}$ ) and vitamin $\mathrm{E}$ (100 IU/ $/ \mathrm{kg})$ supplementation of the diet. Columns with different designations differ significantly $(\mathrm{P}<0.05)$;

* = significant difference between vitamin $\mathrm{E}$ supplemented and unsupplemented treatments $(\mathrm{P}<0.05)$

\section{Discussion}

The results of this study indicated an increase in $\alpha$-tocopherol concentration of the liver with vitamin E supplementation. This was expected and is in agreement with results reported by other authors (Sheldon, 1984; Sheehy et al., 1991). Liver TBARS values and serum GSH were lowered, and serum TAS increased by vitamin E supplementation. Lipid peroxidation is greatly influenced by tissue concentration of $\alpha$-tocopherol, considered to be an important scavenger of free radicals (Comb and Scott, 1977; McKay and Kings, 1980; Sheehy et al., 1991). As vitamin E is greatly responsible for the antioxidant capacity of tissues, serum TAS results were expected to be higher in the vitamin E supplemented diet groups. A possible explanation for decreased GSH in the vitamin E supplemented groups is that with higher vitamin $\mathrm{E}$ concentration less GSH is needed to recycle the antioxidant vitamin. The synthesis of GSH depends on the actual oxidative stress situation as well as on the rate of synth esis because the peptide inhibits its own synthesis through a feedback mechanism (Deleve and Kaplowitz, 1990). The trends of responses to vitamin E supplementation by liver TBARS, plasma TAS, and GSH in the different dietary fat treatments were consistent. A high deposition of n-3 PUFA with a concomitant low deposition of n-6 PUFA observed in this trial with feeding n-3 PFA rich fish oil diet is consistent with the results of previous trials with fish oils (Cherian and Sim, 1992). Liver tissues from chicks fed beef tallow diets rich in SAT and MUFA did not show a higher deposition of these fatty acids. Similar results have been obtained by other authors (Naber and Biggert, 1989; Cherian et al., 1996).

The results of this trial have revealed that increases in tissue oxidation are consistently accompanied by an increase in tissue n-3 PUFA. The high concentr ation of n-3 PUFA predisposes the tissues to oxidative stress and thus increases TBARS and GSH while reducing TAS values.

In conclusion, feeding oils rich in n-3 PUFA increases the tissue concentr ations of these fatty acids, consequently increasing tissue oxidation and reducing the oxidative status of broiler chickens. Supplementing high levels of vitamin E with 
such oils may increase tissue oxidative stability. Serum TAS or GSH may be used as a measure of antioxidative status of chickens. Their use might be of immense importance in monitoring the antioxidative status of growing chickens.

\section{References}

Carew, L. B. and Hill, F. W. (1964): Effects of corn oil on metabolic efficiency of energy utilization by chicks. J. Nutr. 83, 293-299.

Chan, K. M. and Decker, E. A. (1994): Endogenous skeletal muscle antioxidant. Crit. Rev. Food Sci. Nutr. 34, 403-426.

Cherian, G. and Sim, J. S. (1992): Dietary oils and added tocopherols: Effects on egg or tissue tocopherols, fatty acids, and oxidative stability. Lipids $27,706-710$.

Cherian, G., Wolfe, F. W. and Sim, J. S. (1996): Dietary oils and added tocopherols: Effects on egg or tissue tocopherols, fatty acids, and oxidative stability. Poultry Sci. 75, 423-431.

Christon, R., Belcadi, R. H. and Durand, G. (1995): Dietary polyunsaturated fatty acids and ageing modulate glutathione-related antioxidants in rat liver. J. Nutr. 125, 3062-3070.

Comb, G. F. Jr. and Scott, M. L. (1977): Nutritional interrelationships of vitamin E and selenium. Bioscience 27, 467-473.

D’Aquino, M., Benedetti, Di Felice, P. C., Gentili, V., Tomassi, G., Maiorino, M. and Ursini, F. (1991): Effects of fish oil and coconut oil antioxidant defence system and lipid peroxidation in rats. Free Rad. Res. Comm. 12-13, 147-152.

Dam, R., Leach, R. M., Nelson, T. S., Norris, L. C. and Hill, F. W. (1959): Studies on the effect of quantity and type of fat on chick growth. J. Nutr. 68, 615-632.

Dawson, L. E. and Gartner, R. (1983): Lipid oxidation in mechanically deboned poultry. Food Technol. 37, 112.

Deleve, L. D. and Kaplowitz, N. (1990): Importance and regulation of hepatic glutathione. Semin. Liver Dis. 10, 251-266.

Desai, I. D. (1980): Assay Methods. In: Machlin, L. J. (ed.) Vitamin E, A comprehensive treaties. Marcel Dekker Inc., New York. pp. 247-257.

Duncan, D. B. (1955): Multiple range and multiple test. Biometrics 11, 1-42.

Farrell, D. J. and Gibson, R. A. (1990): Manipulation of the composition of lipids in eggs and poultry. Proc. Inaugural Massey, Pig and Poultry Symposium, Massey University, New Zealand. pp. 164-179.

Folch, J., Lees, M. and Sloane-Stanley, G. H. (1957): A simple method of the isolation and purification of total lipids from animal tissues. J. Biol. Chem. 226, 497-509.

Herman, D. (1981): The ageing process. Proc. Natl. Acad. Sci. U.S.A., 78, 7124-7128.

Hulan, H. W., Ackman, R. G., Ratnayake, W. M. N. and Proudfoot, F. G. (1988): Omega-3 fatty acid levels and performance of broiler chickens fed redfish meal and oil. Can. J. Anim. Sci. 68, 533-547.

Hulan, H. W., Ackman, R. G., Ratnayake, W. M. N. and Proudfoot, F. G. (1989): Omega-3 fatty acid levels and general performance of broiler chickens fed reddish meal or reddish oil. Poultry Sci. 68, 153-162.

Husvéth, F., Karsai, F. and Gaál, T. (1982): Peripartal fluctuations of plasma and hepatic lipid contents in dairy cows. Acta Vet. Hung. 30, 97-112.

Lin, C. F., Gray, J. I., Asghar, A., Buckley, D. J., Booren, A. M. and Flegal, C. J. (1989): Effects of dietary oil and $\alpha$-tocopherol supplementation on lipid composition and stability of broiler meat. J. Food Sci. 54, 1457-1460. 
Marusich, W. L., Deritter, E., Ogrinz, E. F., Keating, J., Mitrovc, M. and Bunner, R. H. (1975): Effects of supplemental vitamin $\mathrm{E}$ in control of rancidity in poultry meat. Poultry Sci. 54, 831-844.

McKay, P. B. and Kings, M. M. (1980): Vitamin E: Its role as a biological free radical scavenger and its relationship to the microsomal mixed-function oxidase system. In: Machlin, L. J. (ed.) Vitamin E, A comprehensive treaties. Marcel Dekker Inc., New York. pp. 357-371.

McMurray, C. H., Blanchflower, W. J. and Rice, D. A. (1980): Influence of extraction techniques on the determination of $\alpha$-tocopherol in animal feedstuffs. J. Assoc. Off. Anal. Chem. 63, $1258-1261$.

Molenaar, I., Hulstaert, C. E. and Hardonk, M. J. (1980): Role in function and ultrastructure of cellular membranes. In: Machlin, L. J. (ed.) Vitamin E, A comprehensive treatise. Marcel Dekker Inc., New York. pp. 372-389.

Murphy, M. E., Scholich, H. and Sies, H. (1992): Protection of glutathione and other thiol compounds against the loss of protein thiols and tocopherol homologues during macrosomal lipid peroxidation. Eur. J. Biochem. 210, 139-146.

Naber, E. C. and Biggert, M. D. (1989): Patterns of lipogenesis in laying hens fed a high fat diet containing safflower oil. J. Nutr. 119, 690-695.

Nalbone, G., Leonardi, J., Termine, E., Portugal, H., Lechene, P., Pauli, A. M. and Lafont, H. (1989): Effects of fish oil, corn oil, and lard diets on lipid peroxidation status and glutathione peroxidase activity in rat heart. Lipids 24, 179-186.

National Research Council (1994): Nutritional Requirement of Poultry. 9th revised edition. National Academy Press, Washington.

Noyan, A., Lossow, W. J., Brot, N. and Chaikoff, I. L. (1964): Pathway and form of absorption of palmitic acid in the chicken. J. Lipid Res. 5, 538-541.

Olomu, J. M. and Baracos, V. E. (1991): Influence of dietary flaxseed oils on performance, muscle protein deposition and fatty acid composition of broiler. Poultry Sci. 70, 1403-1411.

Placer, Z. A., Cushman, L. and Johnson, B. C. (1966): Estimation of product of lipid peroxidation (malonyl dialdehyde) in biochemical systems. Anal. Biochem. 16, 359-364.

Rand, N. T., Scott, H. M. and Kummerow, F. A. (1958): Dietary fat in the nutrition of growing chicks. Poultry Sci. 37, 1075-1085.

Sedlak, J. and Lindsay, R. H. (1968): Estimation of total protein-bound and non-protein sulfhydryl groups in tissue with Ellman's reagent. Anal. Biochem. 25, 192-205.

Sheldon, B. W. (1984): Effects of dietary tocopherol on the oxidative stability of turkey meat. Poultry Sci. 63, 673-681.

Sheehy, P. J. A., Morrissey, P. A. and Flynn, A. (1991): Influence of dietary $\alpha$-tocopherol on tocopherol concentrations in chick tissues. Br. Poult. Sci. 32, 391-397.

Sheehy, P. J. A., Morrissey, P. A. and Flynn, A. (1993): Increased storage stability of chicken muscle by dietary $\alpha$-tocopherol supplementation. Irish J. Agric. Food Res. 32, 67-73.

Sim, J. S. (1990): Flaxseed as a high energy/protein/omega-3 fatty acid feed ingredients for poultry. In: Proceeding of the 53rd Flax Institute of the United States, Flax Institute, Fargo. pp. 65-71.

Statgraphics version 5.0 (1991): Statistical Graphic Corporation, Rockville, MD, USA.

Summers, J. D. and Leeson, S. (1979): Comparison of poultry meat as affected by nutritional factors. Poultry Sci. 58, 536-542.

Vermeersch, G. and Vanschoubroek, F. (1968): The quantification of the effects of increasing levels of various fats on body weight gain efficiency of food conversion and food intake of growing chicks. Br. Poult. Sci. 9, 13-30.

Wood, J. D. and Enser, M. (1997): Factors influencing fatty acids in meat and the role of antioxidants in improving meat quality. Br. J. Nutr. 78, 49-63. 